\title{
HUBUNGAN ANTARA PENGETAHUAN METAKOGNITIF DENGAN KEMAMPUAN PEMECAHAN MASALAH MELALUI MODEL PROBLEM BASED LEARNING (PBL) PADA KONSEP PENCEMARAN LINGKUNGAN DI KELAS X
}

\author{
Hanifah Nur Lestari ${ }^{1)}$, Ondi Suganda ${ }^{2)}$, Rahma Widiantie ${ }^{3)}$ \\ 1 Program Studi Pendidikan Biologi FKIP, Universitas Kuningan \\ ${ }^{23}$ Program Studi Pendidikan Biologi FKIP, Universitas Kuningan \\ Email: eyangkamuning@gmail.com \\ Email: rahmawidiantie@gmail.com
}

\begin{abstract}
APA Citation: Lestari, H.N., Suganda, O., \& Widiantie, R. (2017). Hubungan Antara Pengetahuan Metakognitif Dengan Kemampuan Pemecahan Masalah Melalui Model Problem Based Learning (PBL) Pada Konsep Pencemaran Lingkungan Di Kelas X. Quagga: Jurnal Pendidikan dan Biologi, 9(2), 23-31. doi: 10.25134/quagga.v9i02.745.
\end{abstract}

\begin{abstract}
Abstrak: Latar belakang dari penelitian ini adalah proses pembelajaran yang tidak bervariasi menyebabkan siswa kurang mengembangkan keterampilan berpikirnya terutama dalam menyadari pengetahuan metakognitifnya. Akibatnya siswa kesulitan memecahkan permasalahan yang diberikan padahal permasalahan yang diberikan merupakan masalah yang nyata dan sering ditemukan dalam kehidupan sehari-hari. Adapun tujuan dari penelitian ini adalah untuk mengetahui hubungan antara pengetahuan metakognitif dengan kemampuan pemecahan masalah melalui model Problem Based Learning (PBL) pada konsep pencemaran lingkungan. Penelitian ini dilakukan di SMA Negeri 1 Kuningan dengan populasinya adalah seluruh siswa kelas $X$ dan sampel yang digunakan sebanyak 68 siswa yang diambil menggunakan teknik cluster random sampling yang terbagi dalam dua kelas yaitu kelas eksperimen dengan menggunakan model PBL dan kelas kontrol menggunakan model inquiry terbimbing.Desain penelitian ini adalah Posttest Only Control Design. Untuk mengumpulkan data digunakan Metacognitive Awareness Inventory (MAI) dan tes uraian kemampuan pemecahan masalah. Hasil uji $t$ untuk variabel pengetahuan metakognitif menunjukan $t_{\text {hitung }}>t_{\text {tabel }}(4,38>$ 2,65) artinya ada perbedaan yang signifikan antara siswa kelas eksperimen pada hasil tes MAI dengan menggunakan model pembelajaran PBL. Hasil penelitian menunjukan pengetahuan metakognitif siswa kelas eksperimen dikategorikan sangat baik dan siswa kelas kontrol hasilnya dikategorikan baik. Hasil uji $t$ untuk variabel kemampuan pemecahan masalah menunjukan $t_{\text {hitung }}>t_{\text {tabel }}(3,72>2,65)$ artinya ada perbedaan yang signifikan antara siswa kelas eksperimen pada hasil posttest kemampuan pemecahan masalah menggunakan model pembelajaran PBL. Dalam hasil penelitian ini pada total keseluruhan indikator yang tercapai mendapatkan rata-rata total rubrik yang didapat yaitu 3,1 yang menunjukan kriteria baik, sedangkan pada kelas kontrol mendapatkan rata-rata total rubrik yaitu sebesar 2,9 yang menunjukan kriteria baik juga. Hal ini menunjukan bahwa kemampuan pemecahan masalah siswa sudah mencapai kriteria baik pada tiga indikator.Hasil korelasi diketahui $r_{x y}=0,74$ yang berarti memiliki korelasi yang cukup dan berkorelasi positif. Sehingga ada hubungan antara pengetahuan metakognitif siswa dengan kemampuan pemecahan masalah melalui model pembelajaran PBL. Sedangkan rata-rata persentase hasil angket menunjukan 85,29\% siswa merespon positif terhadap pembelajaran menggunakan $P B L$.
\end{abstract}

Kata Kunci : Kemampuan Pemecahan Masalah, Konsep PencemaraLingkungan, Pengetahuan Metakognitif, Problem Based Learning $(P B L)$

\begin{abstract}
The background of this study is that the learning process that does not vary causes students to develop their thinking skills less especially in realizing their metacognitive knowledge. As a result students have difficulty solving problems given even though the problems given are real problems and are often found in everyday life. The purpose of this study was to determine the relationship between metacognitive knowledge and problem solving abilities through the Problem Based Learning (PBL) model on the concept of environmental pollution. This research was conducted at SMA Negeri 1 Kuningan with the population being all students of class $X$ and the sample used as many as 68 students taken using cluster random sampling technique which was divided into two classes namely the experimental class using the PBL model and the control class using the guided inquiry model. The design of this study is Posttest Only Control Design. To collect data used the Metacognitive Awareness Inventory (MAI) and a description of problem solving ability tests. The results of the $t$ test for the metacognitive knowledge variable showed t count> t table (4.38>2.65) meaning that there was a significant difference between the experimental class students on the MAI test results using the PBL learning model. The results showed that the metacognitive knowledge of the experimental class students was categorized very well and the results of the control class students were categorized as good. The results of the t test for the
\end{abstract}


variable problem solving ability showed $t$ count $>t$ table $(3.72>2.65)$ meaning that there was a significant difference between the experimental class students on the posttest results of problem solving abilities using the PBL learning model. In the results of this study on the total overall indicators achieved, the average total rubric obtained is 3.1, which shows good criteria, while in the control class the average total rubric is 2.9 which shows good criteria. This shows that students' problem solving abilities have reached good criteria on three indicators. Correlation results are known to be rxy $=0.74$ which means that it has sufficient correlation and is positively correlated. So there is a relationship between students' metacognitive knowledge and problem solving skills through PBL learning models. While the average percentage of the questionnaire results showed $85.29 \%$ of students responded positively to learning using $P B L$.

Keywords: Problem Solving Ability, Concept of Environmental Pollution, Metacognitive Knowledge, Problem Based Learning (PBL)

\section{PENDAHULUAN}

Berdasarkan hasil observasi di salah satu sekolah, proses pembelajaran yang dilakukan masih berupa ceramah, diskusi, dan praktikum saja namun sudah menggunakan pendekatan saintifik. Selain itu jarang menggunakan model pembelajaran sehingga pembelajaran tidak bervariasi dan latihan soal yang diberikan hanya menekankan pada aspek pengetahuan saja padahal di sekolah tersebut menerapkan kurikulum 2013. Akibatnya pada saat diterapkan model pembelajaran Problem Based Learning (PBL) dan dihadapkan pada suatu permasalahan siswa kesulitan untuk mengidentifikasi dan mencari solusi alternatif untuk memecahkan masalah tersebut. Mereka mengumpulkan informasi dengan cara langsung mencari melalui internet. Hal ini terlihat bahwa peserta didik kurang mengembangkan keterampilan berpikirnya padahal permasalahan yang diberikan merupakan masalah yang nyata dan sering ditemukan dalam kehidupan sehari-hari.

Sehingga dengan cara yang biasa dilakukan siswa seperti itu dapat menyebabkan peserta didik kurang terlatih dalam mengembangkan keterampilan berpikirnya, padahal keterampilan berpikir tingkat tinggi sangat penting terutama dalam pemecahan masalah dan menerapkan sesuai konsep-konsep yang telah mereka ketahui dan mereka pelajari saat pembelajaran untuk diterapkan dalam permasalahan yang terjadi di dunia nyata.

Meskipun dalam mencari solusi permasalahan siswa dapat menggunakan berbagai sumber seperti internet untuk memperoleh informasi tetapi tidak semuanya dapat dijadikan solusi alternatif dalam pemecahan masalah. Hal ini bergantung pada kemampuan metakognitif untuk merencanakan solusi yang terbaik terhadap masalah-masalah yang dihadapi atau mungkin yang dihadapi di kehidupan sehari-harinya. Mereka belajar hanya sekedar ingin tahu dan melaksanakan kewajiban mengisi LKS yang diberikan guru sehingga pembelajaran tidak bermakna dan mudah dilupakan begitu saja.

Salah satu ciri teori belajar dan pembelajaran sejak penerbitan Handbook adalah menekankan pada metode untuk membuat siswa makin menyadari dan bertanggung jawab atas pengetahuan dan pemikiran mereka sendiri (Anderson, 2010). Penelitian menunjukkan bahwa meskipun siswa dapat mempelajari dari informasi yang ada, mereka tidak dapat menggunakan informasi ini untuk memecahkan masalah kehidupan sehari-hari.

Salah satu model pembelajaran yang dapat memfasilitasi siswa untuk mengembangkan keterampilan berpikirnya adalah model pembelajaran Problem Based Learning (PBL), karena dalam PBL siswa tidak hanya mencatat materi penting dan mendengarkan ceramah dari guru saja tetapi disini siswa diajak untuk berfikir secara kritis dan logis. Penerapan model PBL ini diharapkan membawa dampak baik bagi pendidikan dan mengarahkan siswa untuk berpikir tingkat tinggi dibandingkan dengan model pembelajaran konvensional. (Menurut Arends, 2007 dalam Danial, 2010) PBL merupakan suatu strategi pembelajaran dalam hal ini peserta didik mengerjakan permasalahan yang otentik dengan maksud untuk menyusun pengetahuan mereka sendiri, mengembangkan inkuiri dan keterampilan berpikir ke tingkat lebih tinggi, mengembangkan kemandirian dan percaya diri. PBL berfokus pada tantangan yang membuat siswa dapat berpikir.

Sebagaimana inovasi pedagogi pada umumnya, PBL tidak dikembangkan berdasarkan teori pembelajaran atau teori psikologi, namun proses PBL mencakup penggunaan metakognisi dan pengaturan diri dikenal sebagai suatu pendekatan pembelajaran aktif yang progresif dan berpusat kepada pembelajar di mana permasalahan-permasalahan yang tidak terstruktur (dunia nyata atau problema kompleks yang disimulasi/ditirukan) digunakan sebagai titik awal dan akhir selama proses pembelajaran 
(Silver, dkk 2004 dalam Danial, 2010). Hal ini sesuai dengan salah satu karakteristik dari kurikulum 2013 yaitu student centered (berpusat pada siswa).

Untuk membentuk kompetensi yang diharapkan sangat perlu memiliki pengetahuan metakognitif yang mengatur pengetahuan atau kognisi sendiri sehingga mampu mengembangkan kemampuan memecahkan masalah yang bermanfaat bagi kehidupan di masa depan. Menurut Anderson (2010), pengetahuan metakognitif adalah pengetahuan tentang kognisi secara umum dan kesadaran akan, serta pengetahuan tentang, kognisi diri sendiri.

Untuk memperoleh kemampuan dalam pemecahan masalah, siswa diharapkan memahami proses menyesaikan masalah tersebut dan menjadi terampil dalam memilih dan mengidentifikasi kondisi dan konsep yang relevan, mencari generalisasi, merumuskan rencana penyelesaian dan mengorganisasikan yang telah dimiliki sebelumnya (Mariawan, 2013).

\section{METODOLOGI PENELITIAN}

Penelitian ini dilaksanakan di SMA Negeri 1 Kuningan. Waktu pelaksanaan penelitian yaitu pada Semester Genap Tahun Ajaran 2015/2016. Populasi yang digunakan dalam penelitian ini adalah seluruh siswa kelas $\mathrm{X}$ SMAN 1 Kuningan. Sampel sebanyak 68 siswa diambil dengan teknik cluster random sampling yang terbagi dalam dua kelas yaitu kelas eksperimen menggunakan model Problem Based Learning (PBL) berjumlah 34 siswa, dan kelas kontrol menggunakan model inquiry terbimbing berjumlah 34 siswa. Metode penelitian yang digunakan adalah Quasi Experimental. Dengan desain penelitiannya adalah Posttest Only Control Design.

Instrumen penelitian yang digunakan yaitu Metacognitive Awareness Inventory (MAI). MAI dikembangkan oleh Schraw dan SperlingDennison pada tahun 1994 yang diterjemahkan dalam bahasa indonesia dan digunakan untuk mengukur pengetahuan metakognitif seseorang dengan komponen pengetahuan tentang kognisi (knowledge about cognition) dan regulasi kognisi (regulation of cognition) dengan delapan indikator metakognitif. Sedangkan untuk mengukur kemampuan pemecahan masalah digunakan tes uraian yang berisi 3 permasalahan yang harus diselesaikan siswa dengan menggunakan langkah pemecahan masalah DENT.

\section{HASIL DAN PEMBAHASAN AnalisisHasil MAI}

Adapun data yang diperoleh dari hasil angket MAI pada kedua kelas tersebut dapat dilihat pada tabel berikut:

Tabel 1. Deskripsi Data Pengetahuan Metakognitif Kelas Eksperimen dan Kontrol

\begin{tabular}{|c|c|c|c|}
\hline Kelas & N & Rata-rata & SD \\
\hline Eksperimen & 34 & 80,79 & 12,75 \\
\hline Kontrol & 34 & 74,35 & 13,98 \\
\hline
\end{tabular}

Dilihat dari perolehan nilai rata-rata pengetahuan metakognitif berdasarkan hasil tes MAI pada masing-masing kelas yaitu 80,79 pada kelas eksperimen dan 74,35 pada kelas kontrol menunjukan bahwa selama proses pembelajaran dilakukan terdapat perbedaan pengetahuan metakognitif antara siswa dikelas eksperimen dengan siswa di kelas kontrol. Dimana pengetahuan metakognitif kelas eksperimen lebih tinggi daripada pengetahuan metakognitif di kelas kontrol, hal ini karena dikelas eksperimen proses pembelajarannya menggunakan model PBL dengan LKS yang memfasilitasi siswa dalam mengasah pengetahuan metakognitifnya untuk menyelesaikan permasalahan yang disajikan.

Tabel 2. Normalitas Data MAI Kelas Eksperimen dan Kontrol

\begin{tabular}{|c|c|c|c|}
\hline No & Data & $\begin{array}{c}\text { Kelas } \\
\text { Eksperimen }\end{array}$ & $\begin{array}{c}\text { Kelas } \\
\text { Kontrol }\end{array}$ \\
\hline 1 & $\mathrm{~N}$ & 34 & 34 \\
\hline 2 & Rata-rata & 80,79 & 74,35 \\
\hline 3 & $\begin{array}{c}\text { Standar } \\
\text { Deviasi }\end{array}$ & 12,75 & 13,98 \\
\hline 4 & $\chi^{2}$ hitung & 10,97 & 11,05 \\
\hline 5 & $\chi^{2}$ tabel & 11,3 & 11,3 \\
\hline \multicolumn{2}{|c|}{ Kesimpulan } & $\begin{array}{c}\chi^{2} \text { hitung }<\chi_{\text {tabel }}^{2} \\
(\text { Keduanya berdistribusi } \\
\text { normal })\end{array}$ \\
\hline
\end{tabular}

Adapun hasil uji homogenitas data MAI pada kelompok eksperimen dan kelompok kontrol disajikan pada tabel 3. berikut ini:

Tabel 3. Hasil Uji Homogenitas Data Pengetahuan Metakognitif

\begin{tabular}{|c|c|c|c|}
\hline $\begin{array}{c}\text { Kelompok yang } \\
\text { Diuji }\end{array}$ & F hitung & $\begin{array}{c}\mathrm{F} \\
\text { tabel }\end{array}$ & Kesimpulan \\
\hline $\begin{array}{c}\text { Eksperimen dan } \\
\text { Kontrol }\end{array}$ & 1,02 & 2,31 & Homogen \\
\hline
\end{tabular}


Quagga: Jurnal Pendidikan dan Biologi

Volume 9, Nomor 2, Juli 2017

Setelah data di uji homogenitas maka selanjutnya di uji t, hasil uji t di sajikan pda tabel 4. Berikut ini :

Tabel 4. Hasil Uji t Data Pengetahuan Metakognitif

\begin{tabular}{|c|l|l|l|c|}
\hline $\begin{array}{r}\text { Kelompok } \\
\text { yang Diuji }\end{array}$ & $\mathrm{t}$ hitung & $\mathrm{Db}$ & $\mathrm{t}$ tabel & Kesimpulan \\
\hline $\begin{array}{c}\text { Eksperimen } \\
\text { dan kontrol }\end{array}$ & 4,38 & 64 & 2,65 & $\begin{array}{c}\mathrm{H}_{0} \text { ditolak, } \\
\mathrm{H}_{1} \text { diterima }\end{array}$ \\
\hline
\end{tabular}

Dari hasil tabel 4. di atas didapat hasil bahwa $\mathrm{t}_{\text {hitung }}>\mathrm{t}_{\text {tabel }}$ yaitu $4,38>2,65$ maka dan $\mathrm{H}_{0}$ ditolak dan $\mathrm{H}_{1}$ diterima. Artinya ada perbedaan yang signifikan antara siswa kelas eksperimen dan kelas kontrol pada hasil tes MAI terhadap pengetahuan metakognitif siswa pada kelas eksperimen dengan menggunakan model pembelajaran PBL.

Tabel 5. Rekapitulasi Persentase Pengetahuan Metakognitif Siswa Kelas Eksperimen dan

Kontrol

\begin{tabular}{|c|c|c|c|c|c|}
\hline \multirow[b]{2}{*}{ No } & \multirow{2}{*}{$\begin{array}{l}\text { Indikator } \\
\text { Pengetahuan } \\
\text { Metakognitif }\end{array}$} & \multicolumn{2}{|c|}{ Kelas Eksperimen } & \multicolumn{2}{|c|}{ Kelas Kontrol } \\
\hline & & $\begin{array}{c}\text { Rata- } \\
\text { rata }\end{array}$ & Kriteria & $\begin{array}{c}\text { Rata- } \\
\text { rata }\end{array}$ & Kriteria \\
\hline 1. & $\begin{array}{l}\text { Pengetahuan } \\
\text { Deklaratif } \\
\text { (declarative } \\
\text { knowledge) }\end{array}$ & $84,93 \%$ & $\begin{array}{l}\text { Sangat } \\
\text { Baik }\end{array}$ & $80,51 \%$ & $\begin{array}{c}\text { Sangat } \\
\text { Baik }\end{array}$ \\
\hline 2. & $\begin{array}{l}\text { Pengetahuan } \\
\text { Prosedural } \\
\text { (procedural } \\
\text { knowledge) }\end{array}$ & $91,18 \%$ & $\begin{array}{l}\text { Sangat } \\
\text { Baik }\end{array}$ & $86,03 \%$ & $\begin{array}{l}\text { Sangat } \\
\text { Baik }\end{array}$ \\
\hline 3. & $\begin{array}{l}\text { Pengetahuan } \\
\text { Kondisional } \\
\text { (conditional } \\
\text { knowledge) }\end{array}$ & $84,12 \%$ & $\begin{array}{l}\text { Sangat } \\
\text { Baik }\end{array}$ & $80,59 \%$ & $\begin{array}{c}\text { Sangat } \\
\text { Baik }\end{array}$ \\
\hline 4. & $\begin{array}{l}\text { Perencanaan } \\
\text { (planning) }\end{array}$ & $78,15 \%$ & Baik & $74,37 \%$ & Baik \\
\hline 5. & $\begin{array}{l}\text { Strategi } \\
\text { Mengelola } \\
\text { Informasi } \\
\text { (information } \\
\text { management } \\
\text { strategies) }\end{array}$ & $63,24 \%$ & Baik & $52,06 \%$ & Cukup \\
\hline 6. & $\begin{array}{l}\text { Pemantauan } \\
\text { terhadap } \\
\text { pemahaman } \\
\text { (comprehensi } \\
\text { on } \\
\text { monitoring) }\end{array}$ & $91,60 \%$ & $\begin{array}{l}\text { Sangat } \\
\text { Baik }\end{array}$ & $83,61 \%$ & $\begin{array}{c}\text { Sangat } \\
\text { Baik }\end{array}$ \\
\hline 7. & $\begin{array}{l}\text { Strategi } \\
\text { perbaikan } \\
\text { (debugging } \\
\text { strategies) }\end{array}$ & $69,41 \%$ & Baik & $62,35 \%$ & Baik \\
\hline 8. & $\begin{array}{l}\text { Evaluasi } \\
\text { (evaluation) }\end{array}$ & $78,43 \%$ & Baik & $73,04 \%$ & Baik \\
\hline & -rata Total & $80,13 \%$ & $\begin{array}{c}\text { Sangat } \\
\text { Baik }\end{array}$ & $74,07 \%$ & Baik \\
\hline
\end{tabular}

Berikut ini perbandingan persentase ketercapaian tiap indikator pengetahuan metakognitif antarasiswa kelas eksperimen dan kelas kontrol disajikan dalam gambar berikut:
p-ISSN 1907-3089, e-ISSN 2651-5869

https://journal.uniku.ac.id/index.php/quagga

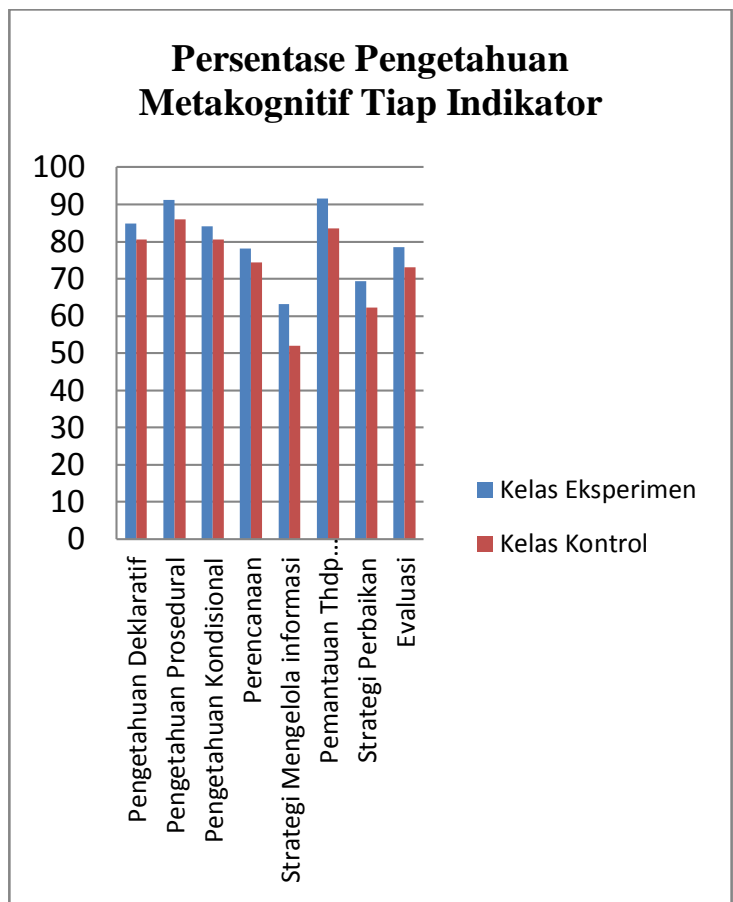

Gambar 1. Grafik Persentase Pengetahuan Metakognitif Siswa

\section{AnalisisHasilTesUraianKemampuanPemecah} anMasalah (Posttest)

Data hasil tes uraian diperoleh dari hasil posttest yang dilaksanakan pada kelas eksperimen dan kelas kontrol. Adapun nilai posttest pada kedua kelas tersebut dapat dilihat pada tabel 6., sebagai berikut:

Tabel 6. Deskripsi Data Kemampuan Pemecahan Masalah Kelas Eksperimen dan Kontrol

\begin{tabular}{|c|c|c|c|}
\hline Kelas & N & Rata-rata & SD \\
\hline Eksperimen & 34 & 72,17 & 8,62 \\
\hline Kontrol & 34 & 66,55 & 8,28 \\
\hline
\end{tabular}

Adapun hasil uji homogenitas data MAI pada kelompok eksperimen dan kelompok kontrol disajikan pada tabel 7 . berikut ini:

Tabel 7. Normalitas Data Posttes Kelas Eksperimen dan Kontrol

\begin{tabular}{|c|c|c|c|}
\hline No & Data & $\begin{array}{c}\text { Kelas } \\
\text { Eksperimen }\end{array}$ & $\begin{array}{c}\text { Kelas } \\
\text { Kontrol }\end{array}$ \\
\hline 1 & $\mathrm{~N}$ & 34 & 34 \\
\hline 2 & Rata-rata & 72,17 & 66,55 \\
\hline 3 & $\begin{array}{c}\text { Standar } \\
\text { Deviasi }\end{array}$ & 8,62 & 8,28 \\
\hline 4 & $\chi^{2}$ hitung & $-50,85$ & $-2,53$ \\
\hline 5 & $\chi^{2}$ tabel & 11,3 & 11,3 \\
\hline \multicolumn{3}{|c|}{ Kesimpulan } & $\begin{array}{c}\chi^{2} \text { hitung } \\
\text { (Keduanya berdistribusi } \\
\text { normal) }\end{array}$ \\
\hline
\end{tabular}


Hasil uji homogenitas data posttest kemampuan pemecahan masalah pada kelompok eksperimen dan kelompok kontrol disajikan pada tabel 8 . berikut ini.

Tabel 8. Hasil Uji Homogenitas Data

Kemampuan Pemecahan Masalah

\begin{tabular}{|c|c|c|c|}
\hline Kelompok yang Diuji & $\begin{array}{c}\mathrm{F} \\
\text { hitung }\end{array}$ & $\begin{array}{c}\mathrm{F} \\
\text { tabel }\end{array}$ & Kesimpulan \\
\hline Eksperimen dan Kontrol & 1,08 & 2,31 & Homogen \\
\hline
\end{tabular}

Adapun hasil uji t pada data kemampuan pemecahan masalah kelompok eksperimen dan kelompok kontrol disajikan pada tabel 9. berikut ini:

Tabel 9. Hasil Uji t Data Kemampuan Pemecahan Masalah

\begin{tabular}{|c|c|c|c|c|}
\hline Kelompok yang Diuji & $\begin{array}{c}\mathrm{t} \\
\text { hitung }\end{array}$ & $\mathrm{Db}$ & $\begin{array}{c}\mathrm{t} \\
\text { tabel }\end{array}$ & Kesimpulan \\
\hline $\begin{array}{c}\text { Eksperimen dan } \\
\text { kontrol }\end{array}$ & 3,72 & 64 & 2,65 & $\begin{array}{c}\mathrm{H}_{0} \text { ditolak, } \\
\mathrm{H}_{1} \text { diterima }\end{array}$ \\
\hline
\end{tabular}

Dari hasil tabel 9. di atas didapat hasil bahwa $t_{\text {hitung }}>t_{\text {tabel }}$ yaitu $3,72>2,65$ maka dan $\mathrm{H}_{0}$ ditolak dan $\mathrm{H}_{1}$ diterima. Artinya ada perbedaan yang signifikan antara siswa kelas eksperimen dan kelas kontrol pada hasil posttest kemampuan pemecahan masalah siswa pada kelas eksperimen dengan menggunakan model pembelajaran PBL.

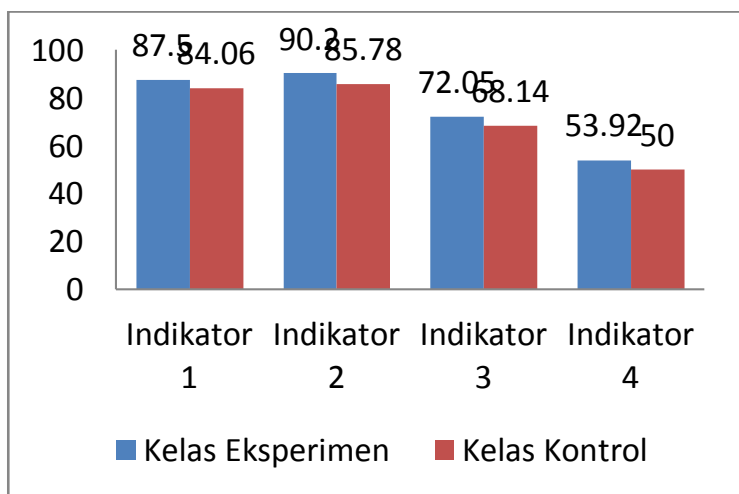

Gambar 2. Grafik Persentase Kemampuan Pemecahan Masalah Siswa

\section{Uji Korelasi}

Uji korelasi dilakukan untuk menghitung korelasi antara variabel pengetahuan metakognitif dengan variabel kemampuan pemecahan masalah siswa. Perhitungan korelasi ini menggunakan rumusan korelasi product moment, dari hasil perhitungan tersebut maka diperoleh nilai korelasi yang disajikan pada tabel 10. sebagai berikut.
Tabel 10. Korelasi Antara Pengetahuan Metakognitif dengan Kemampuan Pemecahan Masalah

\begin{tabular}{|c|c|c|}
\hline Variabel & $\sum$ & $\begin{array}{c}\text { Koefisien } \\
\text { Korelasi }\left(\mathrm{r}_{\mathrm{xy}}\right)\end{array}$ \\
\hline Pengetahuan Metakognitif & 2738 & $\begin{array}{c}0,74 \\
\text { (Cukup) }\end{array}$ \\
\hline $\begin{array}{c}\text { Kemampuan Pemecahan } \\
\text { Masalah }\end{array}$ & 2471 & . \\
\hline
\end{tabular}

Dari hasil tabel 10. di atas diketahui $\mathrm{r}_{\mathrm{xy}}$ yang didapat yaitu 0,74 dapat diinterpretasikan memiliki korelasi yang cukup dan berkolerasi positif karena nilai $r$ menunjukan nilai yang positif. Maka dapat disimpulkan bahwa H1 diterima yaitu ada hubungan antara pengetahuan metakognitif siswa dengan kemampuan pemecahan masalah melalui model pembelajaran PBL.

Dari uji t yang telah dilakukan diperoleh hasil bahwa $t_{\text {hitung }}>t_{\text {tabel }}$ yaitu 4,38>2,65 maka dan $\mathrm{H}_{0}$ ditolak dan $\mathrm{H}_{1}$ diterima, artinya ada perbedaan yang signifikan antara siswa kelas eksperimen dengan siswa kelas kontrol pada hasil tes MAI terhadap pengetahuan metakognitif siswa pada kelas eksperimen dengan menggunakan model pembelajaran PBL.

Hasil penelitian ini sesuai dengan penelitian Danial (2010) bahwa PBL berpengaruh signifikan terhadap keterampilan metakognisi mahasiswa. Hasil penelitian ini juga menunjukkan bahwa skor rata-rata keterampilan metakognisi mahasiswa sejalan dengan skor ratarata penguasaan konsep. Artinya, apabila skor keterampilan metakognisi meningkat, maka skor penguasaan konsep juga cenderung meningkat. Hasil penelitian lainnya yang dilakukan oleh Krisna (2013) mengungkapkan bahwa prestasi belajar siswa dengan menggunakan model PBL berbantu pertanyaan metakognitif jauh lebih baik dibandingkan dengan menggunakan model PBL tanpa berbantu pertanyaan metakognitif. Dengan kata lain dapat dikatakan bahwa pertanyaan metakognitif efektif digunakan baik pada siswa yang memiliki motivasi tinggi maupun motivasi rendah. Penelitian serupa seperti yang dilakukan oleh Celiker (2015) juga menyatakan bahwa dengan pembelajaran dengan menggunakan PBL memberi kontribusi positif pada pengembangan keterampilan metakognitif di berbagai skala. Hal ini dapat dilihat dari hasil uji t yang menyatakan bahwa ada pengaruh yang signifikan antara pretest dan posttest yang telah dilakukan.

Pengaruh model pembelajaran khususnya PBL terhadap peningkatan keterampilan metakognitif yang menunjukkan bahwa proses 
pembelajaran yang berdasarkan penyelidikan atau pembelajaran yang berbasis konstruktivisme (yang mana siswa aktif mencari informasi dan membangun pengetahuan mereka sendiri) dapat menumbuhkan dan mengembangkan proses mengetahui dan proses berpikir mereka atau yang lebih dikenal dengan istilah metakognitif (Arends, 2008).

Hasil penelitian ini menunjukan bahwa ratarata total pengetahuan metakognitif siswa di kelas eksperimen sangat baik yaitu sebesar $80,13 \%$ sedangkan pada kelas kontrol dikategorikan baik dengan persentase sebesar $74,07 \%$. Meski begitu diantara semua indikator pengetahuan metakognitif, indikator strategi mengelola informasi mendapatkan hasil presentase yang paling rendah diantara indikator yang lain. Persentase indikator strategi mengelola informasi di kelas eksperimen menunjukan nilai sebesar 63,24\% dengan kriteria baik dan di kelas kontrol sebesar 52,06\% dengan kriteria cukup. Presentase yang diperoleh indikator ini tidak seperti perolehan persentase pada indikator pengetahuan metakognitif yang lain yang menunjukan nilai yang sangat baik.

Hal ini serupa dengan penelitian sebelumnya yang dilakukan oleh Tosun (2013) yang meneliti pengaruh model pembelajaran Problem Based Learning (PBL) terhadap kesadaran metakognitif pada latar belakang akademik yang berbeda menunjukan bahwa di salah satu sampel yang diteliti pada indikator strategi mengelola informasi tidak menunjukan perbedaan yang signifikan antara pretest dan posttestnya. Hal ini karena siswa tidak mampu belajar bagaimana mengolah informasi secara cepat dan menyelesaikan tugas-tugasnya selama waktu yang ditentukan. Fakta ini menunjukan bahwa untuk mengembangkan indikator strategi mengelola informasi membutuhkan waktu yang cukup lama tidak seperti penelitian ini yang hanya dilakukan selama 5 minggu.

Strategi mengelola informasi merupakan keterampilan dan urutan strategi yang digunakan untuk memproses informasi dengan lebih efisien (misalnya : pengorganisasian, elaborasi, meringkas informasi penting, dan selektif dalam memfokuskan suatu hal). Dalam penelitian ini menunjukan bahwa kemampuan siswa dalam indikator ini tidak terlalu menonjol karena siswa belum mampu untuk mengolah informasi yang diterima yang kemudian diaplikasikan dalam menyelesaikan permasalahan. Hal ini terlihat saat proses penelitian dimana saat berdiskusi dalam menyelesaikan permasalahan yang diberikan guru tidak semua siswa mampu mengaplikasikan informasi ataupun teori yang telah dicari dari berbagai sumber sehingga hanya beberapa siswa saja yang mampu menuangkan pengetahuan tersebut untuk menyelesaikan permasalahan yang diberikan, begitupun terlihat dari hasil LKS dimana jawaban dalam untuk pertanyaan metakognitif yang mengarah pada indikator ini hanya menjawab seadanya tanpa menjelaskan alasan yang seharusnya alasan tersebut dilandasi oleh pengetahuan ataupun informasi penting yang menyangkut penyelesaian masalah tersebut.

Namun dapat disimpulkan dalam penelitian ini PBL memiliki potensi besar untuk mengembangkan dan meningkatkan pengetahuan metakognitif siswa. Meskipun tidak secara langsung hasil persentase menunjukan kriteria yang baik di setiap indikator metakognitif namun dengan cara ini sedikit demi sedikit pengetahuan metakognitif siswa akan berkembang.

Hasil uji t pada data kemampuan pemecahan masalah didapat bahwa $t_{\text {hitung }}>t_{\text {tabel }}$ yaitu 3,72 > 2,65 maka dan $\mathrm{H}_{0}$ ditolak dan $\mathrm{H}_{1}$ diterima, artinya ada perbedaan yang signifikan antara siswa kelas eksperimen dan kelas kontrol pada hasil posttest kemampuan pemecahan masalah siswa pada kelas eksperimen dengan menggunakan model pembelajaran PBL.

Hasil penelitian ini serupa dengan penelitian yang dilakukan oleh Destalia (2014) yang menunjukan bahwa penerapan model pembelajaran berbasis masalah dengan metode eksperimen dapat meningkatkan keterampilan pemecahan masalah siswa pada mata pelajaran biologi baik pada aspek kognitif maupun aspek psikomotorik. Penelitian serupa yang dilakukan oleh Syafii (2013) menunjukan bahwa model pembelajaran berbasis masalah mampu meningkatkan kemampuan pemecahan masalah siswa dalam pelajaran biologi, hal ini di tunjukan dengan adanya peningkatan yang signifikan antara pretest dan posttest pada kelas eksperimen yang menggunakan model pembelajaran berbasis masalah. Hasil penelitian lainnya menurut Paidi (2011) menyatakan bahwa implementasi perangkat pembelajaran berbasis masalah dapat meningkatkan kemampuan pemecahan masalah biologi. Masalah kompleks atau ill-structured problem, yang mewarnai lembar kegiatan siswa (LKS) dalam penelitian ini, sangat berpotensi melatih kemampuan siswa mengenal masalah autentik dan menemukan alternatif-alternatif solusinya. Permasalahan kompleks memerlukan analisis, upaya kooperatif, serta pemikiran dari berbagai sudat pandang untuk dapat mengenal 
dan memecahkannya dengan baik sehingga akhirnya mampu meningkatkan kemampuan pemecahan masalah siswa.

Salah satu bagian dari proses pemecahan masalah adalah pengambilan keputusan (decision making), yang didefinisikan sebagai memilih solusi terbaik dari sejumlah alternatif yang tersedia (Pramana, 2006 dalam Paidi, 2010). Dalam penelitian ini pada total keseluruhan indikator menunjukan persentase yang baik tetapi pada indikator keempat yaitu menguji solusi melalui data empiris hanya mendapatkan persentase sebesar 53,92\% dengan kriteria yang cukup pada kelas eksperimen dan tidak berbeda jauh dengan kelas kontrol yang mendapat presentase indikator menguji solusi melalui data empiris sebesar 50\% saja dengan kriteria yang cukup. Hal ini dikarenakan untuk tercapainya indikator ini dengan memperoleh persentase yang sangat baik dibutuhkan kesiapan siswa memahami teori sehingga solusi pemecahan masalah yang dipilih siswa ini dapat didukung dengan teori yang sebenar-benarnya, namun karena kemampuan siswa terlihat kurang dalam hal mengolah informasi yang diterimanya sehingga pengetahuan siswa untuk menguji solusi disertai data empiris hanya menunjukan hasil dengan kriteria yang cukup.

Hal ini sejalan dengan pernyataan Paidi (2010) yang menyebutkan bahwa kemampuan untuk melakukan pemecahan masalah bukan saja terkait dengan ketepatan solusi yang diperoleh, melainkan kemampuan yang ditunjukkan sejak mengenali masalah, menemukan alternatifalternatif solusi, memilih salah satu alternatif sebagai solusi, serta mengevaluasi jawaban yang telah diperoleh.Pengambilan keputusan yang tidak tepat, akan mempengaruhi kualitas hasil dari pemecahan masalah yang dilakukan. Oleh karena itu indikator ini tidak mendapatkan hasil presentase yang tinggi.

Meskipun begitu keseluruhan pemecahan masalah siswa secara total dinilai baik karena pengaruh dari model pembelajaran yang digunakan yaitu Problem Based Learning (PBL). Hal ini didukung dengan pernyataan bahwa PBL adalah sebuah model pembelajaran yang didasarkan pada prinsip bahwa masalah (problem) dapat digunakan sebagai titik awal untuk mendapatkan atau mengintegrasikan ilmu (knowledge) baru. Tampaknya menyajikan masalah di awal pembelajaran tidak sulit, karena kesempatan ini mengundang rasa ingin tahu siswa, inkuiri, keterlibatan dalam pembelajaran dan motivasi belajar (Tan, 2003 dalam Sastrawati, 2011).

Sementara itu untuk menjawab rumusan masalah mengenai hubungan antara pengetahuan metakognitif dengan kemampuan pemecahan masalah maka peneliti mengkorelasikan nilai tes MAI sebagai data pengetahuan metakognitif dengan hasil posttest tes kemampuan pemecahan masalah di kelas eksperimen. Perhitungan korelasi ini menggunakan rumusan korelasi sederhana yaitu product moment. Hasil koefisien korelasi menunjukan nilai sebesar 0,74 sehingga dapat diinterpretasikan bahwa antara pengetahuan metakognitif dengan kemampuan pemecahan masalah memiliki korelasi yang cukup dan berkorelasi positif. Korelasi positif ini menunjukan terdapat hubungan yang positif artinya jika pengetahuan metakognitifnya tinggi maka kemampuan pemecahan masalahnya akan tinggi.

Hal ini dibuktikan dengan hasil penelitian yaitu berupa nilai angket MAI dan nilai posttest kemampuan pemecahan masalah yang diperoleh tiap siswa rata-rata siswa mendapat hasil MAI tinggi maka hasil posttestnya juga tinggi dan sebaliknya ada juga siswa yang nilai MAI rendah maka nilai posttestnya juga rendah, ini menunjukan keduanya memiliki korelasi yang positif.

Hasil korelasi ini didukung dengan teori menurut Lee dan Fensham, 1996 dalamSimamora (2014) yang menyatakan kemampuan metakognisi melibatkan proses merancang, mengawal dan memantau proses pelaksanaan serta menilai setiap tindakan yang diambil mempunyai peranan yang amat penting dalam proses pembelajaran. Kemampuan metakognisi dapat membantu pelajar untuk menyelesaikan permasalahan melalui perancangan secara efektif melibatkan proses mengetahui masalah, memahami masalah yang perlu dicari solusinya dan memahami strategi yang efektif untuk menyelesaikannya.

Sementara itu hasil yang diperoleh dari penelitian ini memberikan gambaran bahwa untuk mengembangkan pengetahuan metakognitif siswa dan kemampuan pemecahan masalah siswa melalui model pembelajaran Problem Based Learning (PBL) ini baik digunakan dalam proses pembelajaran karena PBL memberi kesempatan lebih banyak kepada siswa untuk mencari informasi dari berbagai sumber belajar dan kebebasan menggunakan berbagai media belajar untuk membangun pengetahuan sendiri (Danial, 2010). 
Selain itu, dalam PBL penyajian masalah yang nyata dan biasa ditemukan sehari-hari oleh siswa mampu mendorong rasa keingintahuan siswa sehingga siswa termotivasi untuk mencari solusi dan menyelesaikan masalah tersebut. Kegiatan ini membuat siswa lebih aktif mencari solusi sebanyak-banyaknya untuk memecahkan permasalahan sehingga siswa menjadi paham terhadap apa yang mereka kerjakan selain itu mendorong siswa untuk memiliki kemampuan pemecahan masalah yang baik.

\section{SIMPULAN}

Dari hasil penelitian dan analisis data yang telah dilakukan maka dapat disimpulkan bahwa ada perbedaan yang signifikan antara siswa kelas eksperimen dan kelas kontrol pada hasil tes MAI terhadap pengetahuan metakognitif siswa pada kelas eksperimen dengan menggunakan model pembelajaran PBL. Hasil penelitian menunjukan pengetahuan metakognitif siswa kelas eksperimen dikategorikan sangat baik dan siswa kelas kontrol hasilnya dikategorikan baik. Dalam hasil penelitian ini pada total keseluruhan indikator yang tercapai mendapatkan rata-rata total rubrik yang didapat yaitu 3,1 yang menunjukan kriteria baik, sedangkan pada kelas kontrol mendapatkan rata-rata total rubrik yaitu sebesar 2,9 yang menunjukan kriteria baik juga. Hal ini menunjukan bahwa kemampuan pemecahan masalah siswa sudah mencapai kriteria baik pada tiga indikator. Sedangkan dalam hal korelasi diketahui $\mathrm{r}_{\mathrm{xy}}$ yang didapat yaitu 0,74 sehingga dapat diinterpretasikan memiliki korelasi yang cukup dan berkolerasi positif. Maka H1 diterima yaitu ada hubungan antara pengetahuan metakognitif siswa dengan kemampuan pemecahan masalah melalui model pembelajaran PBL.

\section{REFERENSI}

Anderson, Lorin W \& David R. Krathwohl. 2010. Kerangka Landasan untuk Pembelajaran, Pengajaran, dan Assesmen Revisi Taksonomi Bloom. Yogyakarta : Pustaka Pelajar.

Arends, Richard I. 2008. Learning To Teach. Yogyakarta : Pustaka Pelajar.

Arikunto, Suharsimi. 2013. Prosedur Penelitian. Jakarta : Rineka Cipta.

Celiker, Huriye D. 2015. Development of Metacognitive Skills: Designing Problem-Based Experiment With Prospective ScienceTeachers in Biology Laboratory.Academic Journals, 10 (11). [online].

Tersedia: http://www.academicjournals.org/ERR [28 Mei 2016]

Danial, Muhammad. 2010. Pengaruh Strategi PBL Terhadap Keterampilan Metakognisi dan Respon Mahasiswa . Jurnal Chemica, 11 (2). [online]. Tersedia : http://ojs.unm.ac.id [12 Januari 2016]

Destalia, Lendy.dkk. 2014. Peningkatan Keterampilan Pemecahan Masalah danHasil Belajar Melalui Penerapan Pembelajaran Berbasis Masalah (PBM) dengan Metode Eksperimen Pada Materi Pencemaran Lingkungan. Pancaran, 3 (4). [online]. Tersedia :http://jurnal.unej.ac.id/index.php/pancar an/article/viewFile/1003/805[12 Januari 2016]

Krisna, Evi Dwi.dkk. 2013. PengaruhModel Pembelajaran Berbasis Masalah Berbantu Pertanyaan Metakognitif Terhadap Prestasi Belajar Matematika Siswa Ditinjau dari Motivasi Berprestasi. e-Journal Program Pascasarjana Universitas Pendidikan Ganesha Program Studi Matematika, 2. [online]. Tersedia: pasca.undiksha.ac.id/565 [12 Januari 2016]

Mariawan, I Made. 2013. Karakteristik Model Pembelajaran Pemecahan Masalah Do Talk Record dalam Sains. Disampaikan pada Seminar Nasional FMIPA UNDIKSHA III. [online].Tersedia: ejournal.undiksha.ac.id/2696 [12 Januari 2016]

Murtadho, Fathiaty. 2013. Berpikir Kritis dan Strategi Metakognisi: Alternatif Sarana Pengoptimalan Latihan Menulis Argumentasi. Makalah Disampaikan pada 2nd International Seminar on Quality and Affordable Education (ISQAE 2013). [online]. Tersedia : educ.utm.my/wpcontent/uploads/2013/1 1/71.pdf.[12 Januari 2016]

OLRC News. 2004. Metacognition. [online]. Tersedia : http://www.literacy.kent.edu/ ohioeff/resource.doc. [12 Januari 2016]

Ormrod, Jeanne Ellis. 2009. Psikologi Pendidikan. Jakarta : Erlangga.

Paidi. 2010. Model Pemecahan Masalah dalam Pembelajaran Biologi di SMA. Artikel Disampaikan Pada Seminar Nasional FMIPA UNY. [online]. Tersedia 
:staff.uny.ac.id/sites.pdf. [02 Februari 2016

Paidi. 2011. Pengembangan Perangkat Pembelajaran Biologi Berbasis Masalah. Jurnal Kependidikan, 41 (2) [online]. Tersedia:http://journal.uny.ac.id/index.p $\mathrm{hp} / \mathrm{jk} / \mathrm{article} / \mathrm{view} / 2225$ [28 Mei 2016]

Sastrawati, Eka. dkk. 2011. Problem Based Learning, Strategi Metakognisi, danKetermpilan Berpikir Tingkat Tinggi Siswa. Tekno-Pedagogi, 1 (2).[online]. Tersedia http://onlinejournal.unja.ac.id/index.php/ pedagogi/article/download/668/5 [12 Januari 2016]

Simamora, Merry C.dkk. 2014. Analisis Kemampuan Metakognisi Siswa Dalam Pembelajaran Biologi Melalui Asessment Pemecahan Masalah di SMA Negeri 5 Kota Jambi. [Skripsi]. FKIP Universitas Jambi. Tidak diterbitkan.

Sugiyono. 2013. Metode Penelitian Pendidikan. Bandung : Alfabeta.

Syafii, W.,\& Ruhizan, M.Y. 2013. Problem Solving Skills and Learning Achievements through Problem-Based Module in teaching and learning Biology in High School. Asian Social Science, 9 (12). [online]. Tersedia : http://dx.doi.org/10.5539/ass.v9n12p220. [28 Mei 2016]

Tosun, C., \& Senocak, E. 2013. The Effects of Problem-Based Learning On Metacognitive Awareness and Attitudes toward Chemistry of Prospective

Teachers with Different Academic Backgrounds. Australian Journal ofTeacher Education, 38 (3). [online]. Tersedia : http://ro.ecu.au/ajte/vol38/iss3/4. [22 Februari 2015] 